\title{
An improved synthesis and some reactions of diethyl 4-oxo-4H-pyran-2,5-dicarboxylate
}

\author{
Dmitrii L. Obydennov $^{\text {a,* }}$, Gerd-Volker Röschenthaler ${ }^{b}$, Vyacheslav Ya. Sosnovskikh ${ }^{a}$ \\ a Department of Chemistry, Ural Federal University, prosp. Lenina 51, 620000 Ekaterinburg, Russia \\ ${ }^{\mathrm{b}}$ School of Engineering and Science, Jacobs University Bremen, Campus Ring 1, 28759 Bremen, Germany
}

\section{A R T I C L E I N F O}

\section{Article history:}

Received 26 July 2013

Revised 3 September 2013

Accepted 20 September 2013

Available online 27 September 2013

Keywords:

Claisen condensation

Ethyl 2-(dimethylamino)methylene-3-

oxobutanoate

Diethyl oxalate

4-Oxo-4H-pyran-2,5-dicarboxylic acid

4-Oxo-1-phenyl-1,4-dihydropyridine-2,5-

dicarboxylic acid

\begin{abstract}
A B S T R A C T
The reaction of ethyl 2-(dimethylamino)methylene-3-oxobutanoate with diethyl oxalate in the presence of sodium hydride in THF gave diethyl 4-oxo-4H-pyran-2,5-dicarboxylate, from which 4-oxo-4H-pyran2,5-dicarboxylic and 4-oxo-1-phenyl-1,4-dihydropyridine-2,5-dicarboxylic acids and their derivatives were obtained in good yields.
\end{abstract}

(c) 2013 Elsevier Ltd. All rights reserved.
Chelidonic acid, a $\gamma$-pyrone compound with the structure shown in Figure 1, is a naturally occurring compound that is widely distributed among many plants. ${ }^{1}$ It is contained in the rhizomes of Chelidonium majus L. at quite high concentrations, and has multiple pharmacological effects including mild analgesic, antimicrobial, oncostatic, and central nervous system sedation. ${ }^{2}$ In addition, chelidonic acid and chelidamic acid were the most potent inhibitors of glutamate decarboxylase from rat brain, ${ }^{3}$ and may attenuate allergic reactions by inhibition of caspase- 1 activity. ${ }^{4}$

Unlike well-studied diethyl chelidonate, ${ }^{5}$ diethyl 4-oxo-4H-pyran-2,5-dicarboxylate (diethyl isochelidonate), is much less known. Furthermore, none of the isomeric 4-pyrone dicarboxylic acids I-III has been recorded in the literature (Fig. 1). Diethyl isochelidonate was mentioned for the first time in 2012 in the patent literature, ${ }^{6}$ as a novel intermediate for synthesizing an anti-influenza drug exhibiting cap-dependent endonuclease inhibitory activity.

$\gamma$-Pyrone derivatives bearing electron-withdrawing carbonylcontaining substituents at the 2- and 5-positions have, surprisingly, been poorly investigated, probably due to the limited number of methods available for their preparation., ${ }^{6,7}$ At the same time, these compounds are an important class of $\gamma$-pyrones which can serve as the starting materials for the syntheses of a broad range of heterocyclic systems due to the presence of five

\footnotetext{
* Corresponding author. Fax: +7 3432615978.

E-mail addresses: dobydennov@mail.ru, obydennov@isnet.ru (D.L. Obydennov).
}

electrophilic centers in their molecules (the C-2, C-4 and C-6 atoms of the pyrone system, and the carbonyl carbons of the 2-COR and 5$\mathrm{COR}^{\prime}$ groups). The diverse range of properties of these compounds is due to the fact that, being highly reactive geminally activated push-pull alkenes with a good leaving group at the $\alpha$ - and $\alpha^{\prime}$-carbon atoms, whose role is played by the enolate anion, they acquire the ability to undergo additional transformations related to $\gamma$-pyrone ring-opening and heterocyclizations.

The present Letter describes an improved synthesis of diethyl isochelidonate (1), which consists of the Claisen condensation of ethyl 2-(dimethylamino)methylene-3-oxobutanoate with diethyl oxalate in the presence of sodium hydride. Moreover, the synthesis<smiles>O=C(O)c1cc(=O)cc(C(=O)O)[nH]1</smiles><smiles></smiles><smiles>O=C(O)c1cocc(C(=O)O)c1=O</smiles>

II<smiles>O=C(O)c1occc(=O)c1C(=O)O</smiles>

Figure 1. Some natural and unnatural $\gamma$-pyrone dicarboxylic acids. 
of 4-pyrone-2,5-dicarboxylic acid [isochelidonic acid (2)] and its derivatives, including $N$-phenylisochelidamic acid, is presented. Although the chemistry of 4-pyrones and 4-pyridones has been well documented, ${ }^{8}$ isochelidonic and isochelidamic acids are hitherto unreported.

Within the framework of a research program on the synthetic opportunities offered by the $\gamma$-pyrone system in the preparation of organic molecules having potential interest in biomedicinal chemistry and materials science, ${ }^{9}$ we had a requirement for large quantities of diethyl 4-oxo-4H-pyran-2,5-dicarboxylate (1). To the best of our knowledge, there has only been one report on the preparation of diester $\mathbf{1}$ via the reaction of ethyl 2-(dimethylamino)methylene-3-oxobutanoate, prepared from ethyl acetoacetate and dimethylformamide dimethyl acetal, ${ }^{10}$ with ethyl oxalyl chloride in the presence of hexamethyldisilazane in THF at $-78^{\circ} \mathrm{C} .{ }^{6}$ However, on repeating this procedure, we were unable to obtain $\mathbf{1}$ in a reasonable yield. Instead, we found that the Claisen condensation of ethyl 2-(dimethylamino)methylene-3-oxobutanoate with diethyl oxalate in the presence of sodium hydride in THF at reflux for $5 \mathrm{~h}$ was the method of choice for the preparation of isochelidonic ester 1. After cooling, the intermediate sodium salt was filtered, washed with THF (yield 64\%), dissolved in water, and quenched with concentrated $\mathrm{HCl}$ to give diester $\mathbf{1}$ in $83 \%$ yield (overall yield 53\%). Note that $\mathbf{1}$ could be prepared without isolation of the sodium salt, however, a higher yield and easier purification of compound $\mathbf{1}$ were possible if the reaction was performed in a two-step approach. Unlike the previously reported method, ${ }^{6}$ this reaction did not require a low temperature or any chromatographic purification of the final product, and thereby greatly facilitated the preparation of the target diester $\mathbf{1}^{11}$ (Scheme 1 ).

As mentioned above, $\gamma$-pyrone-2,5-dicarboxylates belong to a poorly explored class of polycarbonyl compounds, the chemical properties of which have not been investigated. In connection with this, we examined the reactivity of diethyl 4-oxo-4H-pyran-2,5dicarboxylate (1) in order to obtain potentially biologically interesting derivatives. We found that if the hydrolysis of diester $\mathbf{1}$ was carried out under milder conditions (conc. $\mathrm{HCl}, \sim 20^{\circ} \mathrm{C}, 3$ days), the reaction could be stopped at the diacid $\mathbf{2}$ (yield $70 \%$ ), ${ }^{12}$ whereas reflux of 1 in dilute $\mathrm{HCl}$ (1:1) for $7 \mathrm{~h}$ gave comanic acid (3) in $47 \%$ yield, which could also be obtained by decarboxylation of isochelidonic acid (2) under the same conditions (43\% yield). These reactions represent an alternative route to synthesize comanic acid (3). Our approach makes it possible to obtain this compound from acetoacetic ester in three steps (overall yield 25\%), whereas the method described in the literature ${ }^{13}$ for the synthesis of comanic acid (3) consists of five steps and starts from acetone and diethyl oxalate via an acetonedioxalic ester (overall yield 33\%).

There is no significant difference in the chemical reactivity of the 2- and 5-carbethoxy groups, and all our attempts to obtain the monoester starting from diester $\mathbf{1}$ were unsuccessful. Thus, an alternative method for the preparation of 5-carbethoxy-4-pyrone-2-carboxylic acid (4) was developed. We envisaged that the reaction of $\mathbf{1}$ with piperidine would produce the corresponding enaminone $\mathbf{5}$ with one deactivated carbethoxy group, the slow reaction of which with water could be connected with the presence of the electron-donating piperidine moiety. The second carbethoxy group of the compound $\mathbf{5}$ will be activated toward nucleophilic attack by the adjacent carbonyl group. In fact, we found that diethyl isochelidonate $(\mathbf{1})$ reacted readily with piperidine in ethanol at $0{ }^{\circ} \mathrm{C}$ for two hours and then at $-20^{\circ} \mathrm{C}$ over two days to produce compound $\mathbf{5}$ in 59\% yield. This reaction involved attack of the NH group at C-6 of $\mathbf{1}$ with concomitant opening of the pyrone ring to give $\mathbf{5}$, which is a reactive polyfunctionalized intermediate with an intramolecular hydrogen bond. The ${ }^{1} \mathrm{H}$ NMR spectrum of $\mathbf{5}$ displayed broad signals for the piperidine function as a result of its only slightly hindered rotation and there was no evidence of two geometric isomers. ${ }^{10}$ Treatment of amino-enone $\mathbf{5}$ with dilute $\mathrm{HCl}$ led to the starting pyrone $\mathbf{1}$, however, in line with our expectations, basic hydrolysis of compound $\mathbf{5}$ at $0{ }^{\circ} \mathrm{C}$ for $15 \mathrm{~min}$ followed by acidification successfully removed only one ethoxy group to give monoethyl isochelidonate (4) in $72 \%$ yield $^{14}$ (Scheme 2 ).

The structures of pyrones $\mathbf{2}$ and $\mathbf{4}$ were established from their elemental analyses and spectral $\left({ }^{1} \mathrm{H},{ }^{13} \mathrm{C} \mathrm{NMR}\right.$, and IR) data. In their ${ }^{1} \mathrm{H}$ NMR spectra, protons $\mathrm{H}-3$ and $\mathrm{H}-6$ appeared as singlets at $\delta$ 6.94-7.09 and $\delta 8.86-9.00$, respectively, in the ${ }^{13} \mathrm{C}$ NMR spectra, the pyrone carbonyls appeared at $\delta 174.5$ for monoester 4 and $\delta$ 177.5 for diacid 2 (it is well-known ${ }^{15}$ that intramolecular hydrogen bonding causes substantial downfield shifts).

Thus, $\gamma$-pyrone $\mathbf{1}$, due to activation of the conjugated system by two electron-withdrawing carbethoxy groups, is a highly electrophilic substrate, which is able to react with $\mathrm{O}$ - and $\mathrm{N}$-nucleophiles, with or without affecting the pyrone ring. During the preparation of the isochelidamic acid derivatives, it was also found that treatment of $\mathbf{1}$ with aniline at $0{ }^{\circ} \mathrm{C}$ for $30 \mathrm{~min}$ gave amino-enone $\mathbf{6}$ as a $42: 58$ mixture of $E$ - and $Z$-isomers in $81 \%$ yield. It is clear that the diester 1 reacts with aniline exclusively at its 6 -position and in a 1,4-manner. The main information for the characterization of this mixture was obtained from the ${ }^{1} \mathrm{H}$ NMR spectrum in $\mathrm{CDCl}_{3}$, which showed two

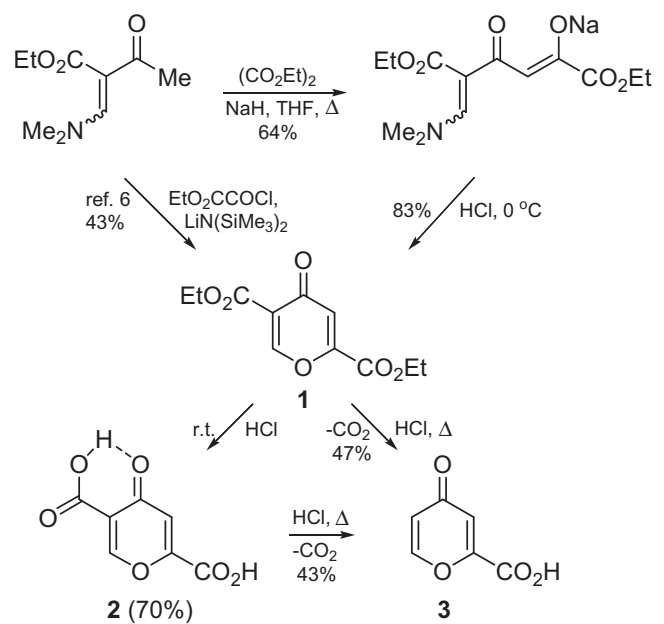

Scheme 1. Synthesis of compounds 1-3.

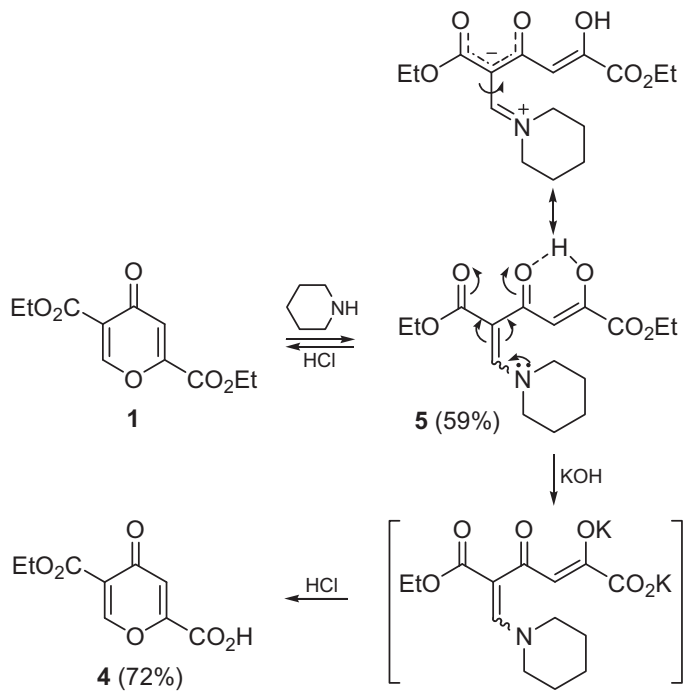

Scheme 2. Synthesis of monoester 4. 
<smiles>CCOC(=O)c1cc(=O)c(C(=O)OCC)co1</smiles>

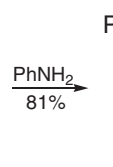<smiles></smiles>
$\frac{\mathrm{MeSO}_{3} \mathrm{H}}{\mathrm{CH}_{2} \mathrm{Cl}_{2}}$

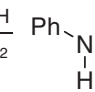

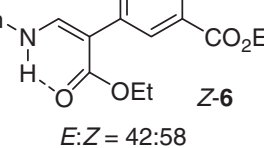

Scheme 3. Synthesis of compounds 6-9.

sets of signals. The most downfield shifted signals at $\delta 15.77(\mathrm{~s}, \mathrm{OH})$, $11.37(\mathrm{~d}, J=14.2 \mathrm{~Hz}, \mathrm{NH}), 8.79(\mathrm{~d}, J=14.2 \mathrm{~Hz},=\mathrm{CHN}), 7.34(\mathrm{~s},=\mathrm{CH})$ and at $\delta 14.55(\mathrm{~s}, \mathrm{OH}), 12.53(\mathrm{~d}, J=13.5 \mathrm{~Hz}, \mathrm{NH}), 8.63(\mathrm{~d}, J=13.5 \mathrm{~Hz}$, $=\mathrm{CHN}), 7.61(\mathrm{~s},=\mathrm{CH})$ were assigned tentatively to isomers $Z-6$ and $E-6$, respectively. These data indicate that both labile protons are involved in the formation of strong intramolecular hydrogen bonds, thus confirming the structure of $\mathbf{6}$.

In comparison to the reaction with piperidine, the use of methanesulfonic acid in dichloromethane at room temperature for three hours transformed amino-enone $\mathbf{6}$ irreversibly into diethyl $N$-phenylisochelidamate (7) in $72 \%$ yield. ${ }^{16}$ Basic hydrolysis of 7 proceeded in the expected manner to give $\mathrm{N}$-phenylisochelidamic acid (8) (yield 88\%), ${ }^{17}$ which may be of interest as a biologically valuable compound. ${ }^{6}$ Despite their rather simple structures, neither compound $\mathbf{7}$ nor its parent acid $\mathbf{8}$ has been prepared previously; from this series of compounds only 5-carbethoxy-4-oxo-1,4dihydropyridine-2-carboxylic acid was known. ${ }^{18}$ Treatment of amino-enone 6 with a catalytic amount of concentrated $\mathrm{HCl}$ in ethanol at room temperature for $12 \mathrm{~h}$ gave a mixture of compounds 9 and 7 in the ratio of 1:3 (yield 48\%) (Scheme 3).

In summary, we have developed an improved synthesis of biologically potent diethyl 4-oxo-4H-pyran-2,5-dicarboxylate, which involves the condensation of ethyl 2-(dimethylamino)methylene3-oxobutanoate with diethyl oxalate in the presence of sodium hydride. Compared with the previously reported procedure, our method shows several advantages, the main of which are simplicity, efficiency, and the ready availability of the starting materials. From this diester, for the first time, isochelidonic acid and its derivatives have been obtained in good yields. Taking into account the ability to transform an ester group into other functional groups, the 4-pyrone-2,5-dicarboxylate core is a valuable building block for the construction of a wide range of 4-pyrone derivatives.

\section{Acknowledgments}

This work was carried out under the terms of Ural Federal University development program with financial support for young scientists. The authors also thank Deutsche Forschungsgemeinschaft for financial support (Grant No. RO 362/45-1).

\section{References and notes}

1. (a) Cavalieri, L. F. Chem. Rev. 1947, 41, 525; (b) Leopold, A. C.; Scott, F. I.; Klein, W. H.; Ramstad, E. Physiol. Plant. 1952, 5, 85; (c) Quin, L. D.; Tyrell, J. A.
Fundamentals of Heterocyclic Chemistry: Importance in Nature and in the Synthesis of Pharmaceuticals; John \& Wiley Sons: New York, 2010. 327 p.

2. Shin, H.-J.; Kim, H.-L.; Kim, S.-J.; Chung, W.-S.; Kim, S.-S.; Um, J.-Y. Immunopharmacol. Immunotoxicol. 2011, 33, 614.

3. Porter, T. G.; Martin, D. L. Biochem. Pharmacol. 1985, 34, 4145.

4. Oh, H.-A.; Kim, H.-M.; Jeong, H.-J. Int. Immunopharmacol. 2011, 11, 39.

5. (a) Katritzky, A. R.; Murugan, R.; Sakizadeh, K. J. Heterocycl. Chem. 1984, 21, 1465; (b) El-Kerdawy, M. M.; Yousif, M. Y. Indian J. Chem. 1985, 24B, 182; (c) Chênevert, R. Goupil, D. Rose, Y. S.; Bédard, E. Tetrahedron: Asymmetry 1998, 9 4285; (d) Schmidt, B. Heterocycles 1999, 51, 179; (e) Lovell, S.; Subramony, P.; Kahr, B. J. Am. Chem. Soc. 1999, 121, 7020; (f) Löwe, W.; Brätter, S. A.; Dietrich, C. J. Heterocycl. Chem. 2002, 39, 77; (g) Hamada, Y.; Ohta, H.; Miyamoto, N.; Yamaguchi, R.; Yamani, A.; Hidaka, K.; Kimura, T.; Saito, K.; Hayashi, Y.; Ishiura, S.; Kiso, Y. Bioorg. Med. Chem. Lett. 2008, 18, 1654; (h) Battilocchio, C.; Baumann, M.; Baxendale, I. R.; Biava, M.; Kitching, M. O.; Ley, S. V.; Martin, R. E. Ohnmacht S. A. Tappin, N. D. C. Synthesis 2012, 44,635: (i) Howáth, G. Rusa, C.; Köntös, Z.; Gerencsér, J.; Huszthy, P. Synth. Commun. 1999, 29, 3719; (j) Pace, P.; Nizi, E.; Pacini, B.; Pesci, S.; Matassa, V.; De Francesco, R.; Altamura, S. Summa, V. Bioorg. Med. Chem. Lett. 2004, 14, 3257.

6. (a) Sumino, Y.; Okamoto, K.; Masui, M.; Akiyama, T. U.S. Patent 0022251, 2012 Chem. Abstr. 2010, 153, 481043.; (b) Kageyama, C.; Mikamiyama, H.; Akiyama, T.; Tomita, K.; Taoda, Y.; Kawai, M.; Anan, K.; Miyagawa, M.; Suzuki, N. WO Patent 039414, 2012, Chem. Abstr. 2012, 156, 477726.; (c) Sumino, Y.; Okamoto, K.; Masui, M.; Yamada, D.; Ikarashi, F. WO Patent 018065, 2012, Chem. Abstr. 2012, 156, 257808.

7. (a) Ross, W. J.: Todd, A.; Clark, B. P.; Morgan, S. E.; Baldwin, J. E. Tetrahedron Lett. 1981, 22, 2207; (b) Clark, B. P.; Ross, W. J.; Todd, A. US Patent 4364956, 1982, Chem. Abstr. 1981, 94, 83945.

8. (a) McCombie, S. W.; Metz, W. A.; Nazareno, D.; Shankar, B. B.; Tagat, J. J. Org. Chem 1991, 56, 4963; (b) El Bakali, J: Muccioli, G. G.: Renault, N.; Pradal, D. Body-Malapel, M.; Djouina, M.; Hamtiaux, L.; Andrzejak, V.; Desreumaux, P.; Chavatte, P.; Lambert, D. M.; Millet, R. J. Med. Chem. 2010, 53, 7918; (c) Henrikson, J. C.; Ellis, T. K.; King, J. B. . J. Nat. Prod. 2011, 74, 1959; (d) Millet, R.; El Bakali, J.; Chavatte, P.; Renault, N.; Lambert, D.; Muccioli, G.; Body-Malapel, M.; Desreumaux, P.; WO Patent 133973, 2010, Chem. Abstr. 2010, 154, 45911.; (e) Ehrlich, M.; Carell, M. Eur. J. Org. Chem. 2013, 77; (f) Zupancic, S.; Svete, J.; Stanovnik, B. Heterocycles 2008, 75, 899; (g) Rudas, M.; Fejes, I.; Nyerges, M. Szöllõsy, Á.; Tõke, L.; Groundwater, P. W. J. Chem. Soc., Perkin Trans. 1 1999, 1167; (h) White, J. D.; Kim, N.-S.; Hill, D. E.; Thomas, J. A. Synthesis 1998, 619; (i) Tamura, Y.; Omori, N.; Kouyama, N.; Nishiura, Y.; Hayashi, K.; Watanabe, K.; Tanaka, Y.; Chiba, T.; Yukioka, H.; Sato, H.; Okuno, T. Bioorg. Med. Chem. Lett. 2012, 22, 5498; (j) Burckhardt, T.; Harms, K.; Koert, U. Org. Lett. 2012, 14, 4674; (k) Brummerhop, H.; Stengelin, S; Heuer, H.; Kilp, S; Herling, A.; Klabunde, T.; Kadereit, D.; Urmann, M. U.S.; Patent 0144862, 2010, Chem. Abstr. 2008, 149 167997.; (1) Patel, B. H.; Mason, A. M.; Barrett, A. G. M. Org. Lett. 2011, 13, 5156; (m) Boukouvalas, J.; Wang, J.-X. Org. Lett. 2008, 10, 3397.

9. (a) Usachev, B. I. Obydennov, D. L · Sosnovskikh, V. Y Russ, Chem Bull, Int Ed 2012, 61, 1596; (b) Obydennov, D. L.; Usachev, B. I. J. Fluorine Chem. 2012, 141 41; (c) Usachev, B. I.; Obydennov, D. L.; Sosnovskikh, V. Y. J. Fluorine Chem. 2012, 135, 278; (d) Usachev, B. I.; Obydennov, D. L.; Kodess, M. I.; Sosnovskikh, V. Y. Tetrahedron Lett. 2009, 50, 4446.

10. Gabbutt, C. D.; Hepworth, J. D.; Heron, B. M. J. Chem. Soc., Perkin Trans. 11992 , 2603.

11. Sodium (5E)-6-(dimethylamino)-1-ethoxy-5-(ethoxycarbonyl)-1,4-dioxohexa-2,5dien-2-olate: A mixture of ethyl 2-(dimethylamino)methylene-3-oxobutanoate $(3.0 \mathrm{~g}, 16.2 \mathrm{mmol})$, diethyl oxalate $(2.84 \mathrm{~g}, 17.3 \mathrm{mmol})$, and $\mathrm{NaH}(60 \%$ dispersion in oil) $(0.84 \mathrm{~g}, 21.0 \mathrm{mmol})$ in THF $(45 \mathrm{~mL})$ was refluxed for $5 \mathrm{~h}$. After cooling, the solid that formed was filtered, washed with THF $(10 \mathrm{~mL})$, and dried. Yield $3.22 \mathrm{~g}(64 \%), \mathrm{mp} 220^{\circ} \mathrm{C}$ (dec.), beige powder. IR (ATR): 2982, 1709, 1689, 1663, $1571 \mathrm{~cm}^{-1}$; ${ }^{1} \mathrm{H}$ NMR (400 MHz, DMSO-d $\left.d_{6}\right) \delta 1.14$ (br t, $J=7.0 \mathrm{~Hz}$, $3 \mathrm{H}, \mathrm{Me}), 1.20(\mathrm{t}, J=7.0 \mathrm{~Hz}, 3 \mathrm{H}, \mathrm{Me}), 2.88\left(\mathrm{~s}, 6 \mathrm{H}, \mathrm{NMe}_{2}\right), 3.97(\mathrm{br} \mathrm{q}, J=7.0 \mathrm{~Hz}, 2 \mathrm{H}$ $\left.\mathrm{CH}_{2} \mathrm{O}\right), 4.05$ (q, J = 7.0 Hz, 2H, CH2O), $5.65(\mathrm{~s}, 1 \mathrm{H},=\mathrm{CH}), 7.14($ br s, $1 \mathrm{H},=\mathrm{CHN}$ ). Diethyl 4-oxo-4H-pyran-2,5-dicarboxylate (1): Sodium (5E)-6-(dimethylamino)1-ethoxy-5-(ethoxycarbonyl)-1,4-dioxohexa-2,5-dien-2-olate (3.0 g, $9.76 \mathrm{mmol})$ was dissolved in $\mathrm{H}_{2} \mathrm{O}(10 \mathrm{~mL})$ and quenched with concentrated $\mathrm{HCl}(3 \mathrm{~mL})$ at $0{ }^{\circ} \mathrm{C}$ (ice bath) for $30 \mathrm{~min}$. The product 1 was extracted with EtOAc $(3 \times 7 \mathrm{~mL})$ and recrystallized from hexane with the addition of small amounts of toluene. Yield $1.94 \mathrm{~g}(83 \%), \mathrm{mp} 71-72{ }^{\circ} \mathrm{C}$ (in Ref. ${ }^{6}$ described as an oil), beige powder. IR (ATR): 3051, 2988, 1751, 1727, 1652, $1572 \mathrm{~cm}^{-1} ;{ }^{1} \mathrm{H}$ NMR $\left(400 \mathrm{MHz}, \mathrm{CDCl}_{3}\right) \delta 1.35(\mathrm{t}, J=7.1 \mathrm{~Hz}, 3 \mathrm{H}, \mathrm{Me}), 1.37(\mathrm{t}, J=7.1 \mathrm{~Hz}, 3 \mathrm{H}, \mathrm{Me}), 4.34$ (q, $J=7.1 \mathrm{~Hz}, 2 \mathrm{H}, \mathrm{CH}_{2} \mathrm{O}$ ), $4.41\left(\mathrm{q}, J=7.2 \mathrm{~Hz}, 2 \mathrm{H}, \mathrm{CH}_{2} \mathrm{O}\right), 7.18(\mathrm{~s}, 1 \mathrm{H}, \mathrm{H}-3), 8.53$ (s, $1 \mathrm{H}, \mathrm{H}-6)$.

12. 4-Oxo-4H-pyran-2,5-dicarboxylic acid (isochelidonic acid) (2): A solution of diester $1(0.20 \mathrm{~g}, 0.83 \mathrm{mmol})$ in concentrated $\mathrm{HCl}(2 \mathrm{~mL})$ was stirred for $3 \mathrm{~d}$ at room temperature. The resulting solid was filtered, washed with $\mathrm{H}_{2} \mathrm{O}$, and then toluene. Yield $0.117 \mathrm{~g}(70 \%), \mathrm{mp} 288-290{ }^{\circ} \mathrm{C}$ (dec.), beige powder. IR (ATR): 3530, 3428, 3084, 1751, 1713, 1662, 1605, $1560 \mathrm{~cm}^{-1} ;{ }^{1} \mathrm{H}$ NMR (400 MHz, DMSO-d $\left.{ }_{6}\right) \delta 7.09$ (s, $\left.1 \mathrm{H}, \mathrm{H}-3\right), 9.00(\mathrm{~s}, 1 \mathrm{H}, \mathrm{H}-6), 11.0-15.0(\mathrm{br} \mathrm{s}, 2 \mathrm{H}, 2 \mathrm{OH}) ;{ }^{13} \mathrm{C}$ NMR $\left(100 \mathrm{MHz}, \mathrm{DMSO}-d_{6}\right) \delta 119.9,120.4,154.8,160.7,163.0,163.7,177.5$ Anal. Calcd for $\mathrm{C}_{7} \mathrm{H}_{4} \mathrm{O}_{6} \cdot \mathrm{H}_{2} \mathrm{O}$ : C, 41.60; $\mathrm{H}, 2.99$. Found: $\mathrm{C}, 41.66 ; \mathrm{H}, 2.75$.

13. (a) Ruzicka, L.; Fornasir, V. Helv. Chim. Acta 1920, 3, 806; (b) Attenburrow, J.; Elks, J.; Elliott, D. F.; Hems, B. A.; Harris, J. O.; Brodrick, C. I. J. Chem. Soc. 1945, 571; (c) Garkusha, G. A.; Khutornenko, G. A.; Kurakina, N. A. Zh. Org. Khim. 1967, 3, 1699. Chem. Abstr. 1968, 68, 29530.

14. 5-(Ethoxycarbonyl)-4-oxo-4H-pyran-2-carboxylic acid (4):A mixture of aminoenone 5 (120 mg, $0.37 \mathrm{mmol})$ and $\mathrm{KOH}(103 \mathrm{mg}, 1.83 \mathrm{mmol})$ in $\mathrm{H}_{2} \mathrm{O}(2 \mathrm{~mL})$ was 
stirred for 15 min at $0{ }^{\circ} \mathrm{C}$ and quenched with $4 \mathrm{M} \mathrm{HCl}$ until $\mathrm{pH} 1$. The resulting solid was separated by filtering and washed with cold $\mathrm{H}_{2} \mathrm{O}$. Yield $56 \mathrm{mg}(72 \%)$, mp $238-240^{\circ} \mathrm{C}$, white powder. IR (ATR): 3071, 3006, 1729, 1641, 1592, $1560 \mathrm{~cm}^{-1} ;{ }^{1} \mathrm{H}$ NMR (400 MHz, DMSO-d 6 ) $\delta 1.27$ (q, $\left.J=7.1 \mathrm{~Hz}, 3 \mathrm{H}, \mathrm{Me}\right), 4.24(\mathrm{q}$, $\left.J=7.1 \mathrm{~Hz}, 2 \mathrm{H}, \mathrm{CH}_{2} \mathrm{O}\right), 6.94(\mathrm{~s}, 1 \mathrm{H}, \mathrm{H}-3), 8.86(\mathrm{~s}, 1 \mathrm{H}, \mathrm{H}-6)$ (the $\mathrm{OH}$ proton was not observed due to broadening): ${ }^{13} \mathrm{C}$ NMR $\left(100 \mathrm{MHz}\right.$, DMSO- $\left.d_{6}\right) \delta 14.5,61.4,120.5$, 121.7, 153.8, 161.0, 161.9, 162.6, 174.5. Anal. Calcd for $\mathrm{C}_{9} \mathrm{H}_{8} \mathrm{O}_{6}$ : C, 50.95; $\mathrm{H}$, 3.80. Found: C, $51.07 ; \mathrm{H}, 3.54$

15. Stothers, J. B.; Lauterbur, P. C. Can. J. Chem. 1964, 42, 1563.

16. Diethyl 4-oxo-1-phenyl-1,4-dihydropyridine-2,5-dicarboxylate (7): A solution of amino-enone $6(200 \mathrm{mg}, 0.60 \mathrm{mmol})$ and $\mathrm{MeSO}_{3} \mathrm{H}(115 \mathrm{mg}, 1.2 \mathrm{mmol})$ in $\mathrm{CH}_{2} \mathrm{Cl}_{2}(2 \mathrm{~mL})$ was stirred for $3 \mathrm{~h}$. The solvent was removed and the residue was diluted with $\mathrm{H}_{2} \mathrm{O}$. The solid that formed was filtered and recrystallized from hexane-toluene $(4: 1)$. Yield $147 \mathrm{mg}(72 \%), \mathrm{mp} 141-142{ }^{\circ} \mathrm{C}$, colorless crystals. ${ }^{1} \mathrm{H}$ NMR $\left(400 \mathrm{MHz}, \mathrm{CDCl}_{3}\right) \delta 1.08(\mathrm{t}, J=7.1 \mathrm{~Hz}, 3 \mathrm{H}, \mathrm{Me}), 1.37(\mathrm{t}$
$J=7.1 \mathrm{~Hz}, 3 \mathrm{H}, \mathrm{Me}), 4.11\left(\mathrm{q}, J=7.1 \mathrm{~Hz}, 2 \mathrm{H}, \mathrm{CH}_{2} \mathrm{O}\right), 4.37\left(\mathrm{q}, J=7.1 \mathrm{~Hz}, 2 \mathrm{H}, \mathrm{CH}_{2} \mathrm{O}\right)$ $7.06(\mathrm{~s}, 1 \mathrm{H}, \mathrm{H}-3), 7.28-7.32(\mathrm{~m}, 2 \mathrm{H}, \mathrm{Ph}), 7.50-7.54(\mathrm{~m}, 3 \mathrm{H}, \mathrm{Ph}), 8.27(\mathrm{~s}, 1 \mathrm{H}, \mathrm{H}-$ 6); ${ }^{13} \mathrm{C}$ NMR $\left(100 \mathrm{MHz}, \mathrm{CDCl}_{3}\right) \delta 13.5,14.2,61.2,62.6,119.5,124.9,125.1$, $129.5,129.8,140.3,142.2,148.1,161.3,164.2,174.8$. Anal. Calcd for $\mathrm{C}_{17} \mathrm{H}_{17} \mathrm{NO}_{5}$ : C, 64.75; H, 5.43; N, 4.44. Found: C, 64.58; H, 5.32; N, 4.27.

17. 4-Oxo-1-phenyl-1,4-dihydropyridine-2,5-dicarboxylic acid (8): To a suspension of diester 7 (100 mg, $0.32 \mathrm{mmol})$ in $\mathrm{H}_{2} \mathrm{O}(2 \mathrm{~mL})$ was added $\mathrm{KOH}(107 \mathrm{mg}$ $1.90 \mathrm{mmol}$ ) and the mixture was stirred at room temperature $(30 \mathrm{~min})$ and then at reflux ( $30 \mathrm{~min}$ ). After cooling, the mixture was quenched with $4 \mathrm{M} \mathrm{HC}$ until $\mathrm{pH} 1$, and the solid that formed was filtered and washed with $\mathrm{H}_{2} \mathrm{O}$. Yield $72 \mathrm{mg}(88 \%), \mathrm{mp} 223-224{ }^{\circ} \mathrm{C}$, colorless powder. ${ }^{1} \mathrm{H}$ NMR $\left(400 \mathrm{MHz}\right.$, DMSO- $\left.d_{6}\right) \delta$ $7.15(\mathrm{~s}, 1 \mathrm{H}, \mathrm{H}-3), 7.52-7.58(\mathrm{~m}, 5 \mathrm{H}, \mathrm{Ph}) .8 .49(\mathrm{~s}, 1 \mathrm{H}, \mathrm{H}-6)$ (the $\mathrm{OH}$ protons were not observed due to broadening). Anal. Calcd for $\mathrm{C}_{13} \mathrm{H}_{9} \mathrm{NO}_{5}$ : C, 60.24; $\mathrm{H}, 3.50$; N, 5.40. Found: C, 60.10; H, 3.29; N, 5.45.

18. Domagala, J. M. J. Org. Chem. 1984, 49, 126. 